August 2009

\title{
The Problem of Ethnic Politics and Trust: The Missing Persons Institute of Bosnia-Herzegovina
}

Kirsten Juhl

Follow this and additional works at: https://digitalcommons.usf.edu/gsp

\section{Recommended Citation}

Juhl, Kirsten (2009) "The Problem of Ethnic Politics and Trust: The Missing Persons Institute of BosniaHerzegovina," Genocide Studies and Prevention: An International Journal: Vol. 4: Iss. 2: Article 14. Available at: https://digitalcommons.usf.edu/gsp/vol4/iss2/14

This Articles is brought to you for free and open access by the Open Access Journals at Digital Commons @ University of South Florida. It has been accepted for inclusion in Genocide Studies and Prevention: An International Journal by an authorized editor of Digital Commons @ University of South Florida. For more information, please contact digitalcommons@usf.edu. 


\title{
The Problem of Ethnic Politics and Trust: The Missing Persons Institute of Bosnia-Herzegovina
}

\author{
Kirsten Juhl \\ Research Fellow, University of Stavanger
}

\begin{abstract}
After the violent conflict in the 1990s, between 25,000 and 30,000 persons were missing in Bosnia-Herzegovina (BiH), their fates and whereabouts unknown. Solving the missing-persons issue, and thus reducing some of the damages of the conflict, has been important in the aftermath crisis management and has been considered a prerequisite to prevent recurrences. Two of the latest developments in these efforts are the adoption of the Law on Missing Persons in October 2004 and the establishment of a state-level institution, the Missing Persons Institute (the MPI $\mathrm{BiH}$ ) in August 2005. This article examines the missing-persons issue from a risk management and societal safety perspective aimed at creating resilient societies. The state is regarded as a key actor, even when other actors are involved and considered co-responsible. Especially important is the state's ability to establish public confidence in critical social institutions and to build mutual trust among different groups within the population. Based on empirical data, the article explores risk factors and dynamics that may threaten the MPI BiH's ability to contribute to societal safety in a society that has run into what is conceptualized as a social trap. To get out of this trap, parties who profoundly distrust one another will need to cooperate. Explicit as well as implicit objectives, competing rationalities, and perceptions of reality among key actors are discussed. The article also considers how the emotional overrules the rational, how the predominantly ethnic discourse in society overpowers the weaker human-rights discourse, and how this may threaten the important building of confidence and trust.
\end{abstract}

Keywords: ethnic conflict, missing persons, societal safety, social traps, trust and distrust

\section{Introduction}

The Balkan wars of the 1990s were a complex crisis developing along the lines of ethnic division and polarization. In Bosnia-Herzegovina $\left(\mathrm{BiH}^{1}\right)$, the Dayton Peace Agreement of 1995 put an end to violence but also essentially cemented the divisions and demographic patterns established in $\mathrm{BiH}$ during the war, splitting the country in two autonomous territorial and administrative entities. At war's end, an estimated 30,000 persons were missing, and their fates and whereabouts unknown. Resolving the missing-persons issue, and thereby mitigating the damage caused by the violent ethnonational conflict, has played an important role in the aftermath crisis management. Investigations of mass graves and subsequent identification of the exhumed mortal remains have been conducted at a scale so far unparalleled in the world, and the results are also unparalleled. Since 1997, assisted by the International Commission on Missing Persons (ICMP), entity-level commissions on missing persons and local authorities have conducted recovery and repatriation operations of victims of

Kirsten Juhl, "The Problem of Ethnic Politics and Trust: The Missing Persons Institute of Bosnia-Herzegovina." Genocide Studies and Prevention 4, 2 (August 2009): 239-270. (C) 2009 Genocide Studies and Prevention. doi: 10.3138/gsp.4.2.239 
their own ethnicities on each other's territory-the so-called Joint Exhumation Process (JEP). This arrangement, however, upheld a division along the lines of ethnicity; true cooperation has been difficult, and has involved harsh mutual accusations of deliberate obstructionism on both sides.

Two of the latest efforts to change this pattern are the adoption in October 2004 of the Law on Missing Persons, detailing the rights of family members of missing persons as well as the duties of state authorities, ${ }^{2}$ and the establishment of a state-level institution, the Missing Persons Institute of Bosnia and Herzegovina (MPI BiH), as one of the provisions of this law. ${ }^{3}$ This institution was co-founded by the Council of Ministers of $\mathrm{BiH}$ and the ICMP in August 2005. ${ }^{4}$ It will merge the two previously existing entity-level commissions, the Federal Commission on Missing Persons (Federal Commission) and the Office for Tracing Detained and Missing Persons of the Republika Srpska (RS Office), and take over their work, staff, and duties. Through representation in an advisory board, families of missing persons will get a formal role in the process. The stated objective of the MPI BiH is to speed up the process and increase the efficiency of activities related to establishing the fate and whereabouts of missing persons by centralizing and coordinating all efforts in one body. A highly important task will be the creation of a unique and rigorously verified Central Record of Missing Persons in $\mathrm{BiH}(\mathrm{CEN} \mathrm{BiH}) .{ }^{5}$ The crux is that in accordance with the Law on Missing Persons, all activities are to be carried out exclusive of "any form of discrimination, including sex, race, skin colour, language, religion, political or other beliefs, national and social origin, inclusion in a national minority group, property status, age, mental or physical disability, status acquired by birth, or any other status"6_-whether among the missing or among their family members. By lifting these activities up from the entity level to the state level, one is basically trying to replace a predominantly ethnic discourse (focusing on collective ethnonational interests based on perceived group characteristics) that also affects the missing-persons issue with a human-rights discourse (focusing on the needs and rights of individuals) and to foster intergroup trust through institutional intergroup cooperation. A further goal is to draw the attention and awareness of political parties to resolving the issue rather than abusing and manipulating it as a convenient means to other political ends.

This article addresses the issue from the perspectives of risk management and societal safety, focusing on the importance of trust and trustworthiness in discussing factors that may put at risk the MPI BiH's ability to change the prevailing discourse, create confidence in its work, and build trust among the families of the missing across ethnonational dividing lines. In doing so, it takes into consideration the external pressures from a society still characterized by institutionalized polarization along ethnonational lines, attended by profound interethnic distrust and widespread denial or strongly biased interpretations of what happened during the war and further exacerbated by the dominance of chauvinistic nationalist partisan politics. The article is based on a study of a process that is still under way; it primarily covers the implementation period of the MPI $\mathrm{BiH}$, from the drafting of the Law on Missing Persons and the protocol for establishing the institute, starting in 2003, to its coming into full functionality (in terms of having a full staff and steering functions in place, ready to proceed to operation), from 2008 onward.

\section{Methods}

The findings presented in the article are based on a critical review of a variety of sources, analyzed for their content in accordance with the principles of historical 
source criticism. Source categories taken into account are related empirical studies and research reports; official and semi-official documents; internal reports by key institutions; English press summaries by ICMP of articles related to the missingpersons issue in Bosnian-Herzegovinian written news media from December 2004 through 2007; ICMP press releases from 2003 through 2007, usually carried in full text or reported on by a number of local media; qualitative interviews with key actors relevant to the missing-persons issue, conducted in June 2005 and November/ December 2006; field conversations; and participant and non-participant observation data.

Field trips to $\mathrm{BiH}$ included a three months' secondment to the ICMP as an archaeologist-my original profession-in 2005, through the Norwegian Resource Bank for Democracy and Human Rights (NORDEM). ${ }^{7}$ This trip made me realize that although forensic science is a tremendously important and indispensable contributor, perfecting the forensic sciences is not the main key to resolving the missing-persons issue in $\mathrm{BiH}$. In 2006 and 2007, I spent a total of two-and-a-half months doing research in $\mathrm{BiH}$, during which time, in addition to conducting interviews, I had the opportunity to engage in field conversations and make observations on the interactions among key actors by attending and/or participating in various events such as exhumations, commemorations, burials, conferences, and everyday work situations. Key actors more formally interviewed were the head of BiH's Department for Protection of Human Rights at the Ministry for Human Rights and Refugees (MHRR); the then chair of the MPI Board of Directors; nine leadership representatives of Bosniak, Croat, and Serb missing-person family associations and/or their umbrella organizations, four of whom are also members of the MPI BiH Advisory Board; and the director of the ICMP's Civil Society Initiatives Department. All interviews were conducted face to face, those with Bosnian-Herzegovinians with the help of interpreters. ${ }^{8}$ Two were unstructured interviews; the rest were semi-structured, based on an interview guide discussed in detail with the interpreters.

The press summaries used total about 5,600 individual entries, predominantly from the daily newspapers Dnevni avaz, Dnevni list, Glas Srpske, Nezavine novine, and Oslobodenje; the weekly magazines Slobodna Bosna and DANI; the online news agency FENA; and the online Bosnia Daily. ${ }^{9}$ Frequently these entries are accompanied by a comment that the same news was carried by other named local news media as well. The press summaries cover the whole spectrum of the missing-persons issue: exhumations, DNA identification issues, anniversaries and reports on people missing after specific war events, commemorations, burials, opinions and statements by key actors, reactions to court procedures, problems concerning witnesses, and so on. About 450 entries directly cover the Law on Missing Persons and/or the MPI BiH. As a source on the character of the public discourse in $\mathrm{BiH}$ around this issue, they are invaluable.

\section{Theoretical Perspectives}

\section{Societal Safety and the Necessity of Trust and Trustworthiness}

In a white paper to the Norwegian Parliament in 2002, the concept societal safety was defined as "the ability society has to maintain critical societal functions, protect the life and health of the citizens and meet their basic requirements in a variety of stress situations." 10 The focus is on preventing undesirable events, characterized by extraordinary stresses and losses and occurring in complex and interdependent systems, that undermine trust in vital social functions. Societal safety further involves an ability to reduce the damage done by such events when they do nonetheless occur 
and to establish normal conditions as soon as possible after such events. Even when other actors are involved and are considered co-responsible, the state is regarded as a key actor and the ultimate guarantor of societal safety, the very idea of which rests on a precautionary principle and aims to create a society that is essentially resilient to various intentionally as well as unintentionally imposed threats and dangers. Especially important is the state's ability to establish and maintain public confidence in critical social institutions and to build mutual trust among different groups within the population. ${ }^{11}$

Of course, this is a far easier task in a society like Norway's-where the levels of generalized trust are the highest in the world, ${ }^{12}$ where people have fair reason to trust their institutions, and where the undesirable events so far encountered have never caused a complex emergency, defined by a "total or considerable break down of authority resulting from internal or external conflict" requiring "an international response that goes beyond the mandate or capacity of any single agency and/or the ongoing United Nations country program"13 — than in a society that has experienced a complex emergency and where, in consequence, trust in both authorities and other individuals and groups within society has been fundamentally undermined.

Violent ethnonational conflicts are complex political and humanitarian crises. This type of crisis often has a long incubation period, characterized by escalating tensions and unresolved conflicts that may turn into repeated violent incidents before it reaches the peak of full-blown armed conflict and becomes a complex emergency. They are also slow-burning crises characterized by profound long-term consequences closely interrelated with other dimensions of the crisis. Handling these consequences is one of the major challenges in the aftermath of a complex crisis. The boundaries between conflict and post-conflict are blurred; "post-conflict" is a misleading term, as conflict is often continued by other means after arms have been laid down, and hence in the aftermath one can expect "crises after the crisis." 14 If issues at the root of the conflict are not adequately addressed, the vicious circle may very well start over again-even after a protracted period. The way one chooses to manage the aftermath makes a difference to whether or not society proceeds towards sustainable peace.

This choice cannot be seen independently of the conditions that one desires should characterize future society (i.e., be the normal conditions of society). As these definitely should not be the same as those that led society toward massive humanrights abuses, in the aftermath, society will be in transition, plowing unfamiliar ground in its efforts to establish rather than reestablish order, to build rather than rebuild society. In such a society, societal safety is not about improving by degrees an already existing safety but about creating that safety it from scratch. However, strengthening societal safety in the larger society and in local communities, even by degrees, is an important goal that may help diminish the threat of the vicious circle's beginning again. If societal safety is to be sustainable, there are no alternatives to the state assuming its responsibilities. ${ }^{15}$ Even if the presence of the international community and of international relief organizations may be needed for years after war's end, the incorporation of local knowledge, resources, institutions, and selforganized victim groups is paramount to achieve this goal of societal safety successfully.

Societal safety must be created from within the affected society itself, from the top down and from the bottom up simultaneously, in order to establish a sustainable institutional and organizational framework and ensure a broad-based commitment to and a collective sense of ownership of both the problems and, not least, their 
resolution. From a public planning perspective, the first is usually sought by applying an instrumental rationality that is top-down, benchmarking and document oriented, focusing on long-term objectives to govern short-term goals. Problem solving is viewed as a sequential, linear process. Ideally, one analyzes the problem at hand, benchmarks the alternative solutions and their consequences, chooses the best option, implements it, and thus achieves the preferred result. This is the kind of rationality that usually characterizes the ideal Weber bureaucrat, the professional administrator, and the scientific expert; it is supposed to be efficient and expedient and to create a foundation for the qualities that promote trust in institutions. The second is supposedly achieved through applying a communicative rationality, which is process oriented and consensus seeking and which may thus promote intergroup trust. It is sometimes conceptualized as a bottom-up process that provides everyone involved with a feeling of ownership of the chosen solution. In principle, decisions are reached through open dialogue among all stakeholders in the case. Ideally, all stakeholders are honest and sincere, fully and equally informed, and equally capable of attending to their interests and making themselves heard, and have equal influence on the outcome. ${ }^{16}$

\section{Trust as Social Capital}

Ever since Robert Putnam, in an empirical study of what makes democracy work in Northern Italy, coined the concept of trust as social capital brought about predominantly by extensive public engagement in civil society networks, ${ }^{17}$ trust as a social mechanism has become the topic of extensive research within the social sciences. Regardless of whether trust is conceptualized as a cognitive, psychological, or moral property of individuals, social relationships, or the social system itself, social trust is widely believed "to promote democratization, economic investments and growth, responsive and well-performing institutions, low levels of violence and other criminal behavior, as well as individual health and personal happiness." 18 A main reason for this is that by fostering dialogue and mutual cooperation, social trust reduces the transaction costs involved in human interaction-that is, it reduces the costs and efforts of rule enforcement, whether through legal or social sanctions, and the additional costs of elaborate control systems, whether formal or informal. As Bo Rothstein points out, like other kinds of capital, physical or human, social capital should be viewed as an asset possessed by individuals, organizations, and societies. ${ }^{19}$ Rothstein suggests that social capital has both quantitative and qualitative dimensions, the quantitative dimension being an actor's number of social relationships and the qualitative being the quality of trust in these relationships. Social capital, however, differs from physical capital, and to some degree from human capital, in that it grows with use, cannot be bought, and is difficult to measure. In this connection it is important to remember that capital can be invested both wisely and unwisely, that only wisely invested capital yields a good return, and that to invest at all, start-up capital is required.

This has implications for society's ability to establish and maintain societal safety. A person cannot feel safe in society if he or she has little or no trust in those responsible for this safety. Hence, these social institutions need to develop their assets of credibility and trustworthiness. Institutional trust refers to trust in the functioning of organizational, institutional, and social systems. According to Daniel Metlay, this kind of trust rests on "two distinctly different components or dimensions: (1) a tightly interconnected and intertwined set of affective beliefs about institutional behaviour, and (2) how competent the institution appears to be." ${ }^{20}$ Affective elements are openness 
(all relevant, unclassified information is provided to the public), reliability and consistency (sincere commitment and genuine effort to keep promises), integrity and honesty (actions consistent with words and not unduly influenced by politics), credibility (facts not distorted), fairness (commitment to impartiality and acting in good faith), and caring and concern for the broad public interest (listening to the public); whereas competence is measured by the possession of the necessary skills to carry out the work and a first-class staff. ${ }^{21}$ These are exactly the qualities called for by representatives of the families of missing persons as a condition for them to trust the authorities and the work of the MPI BiH: transparency, accountability, predictability, impartiality, and strong inclusion of their own participation in the process; professionalism, efficiency, and deliverability. The crux of the matter, however, is not whether an institution actually possesses these qualities but whether it is perceived to possess them by those who depend on its work. Of course, the first is a prerequisite for the second, but the second does not automatically follow from the first. Both need constant attention and maintenance.

\section{Getting into Social Traps}

$\mathrm{BiH}$ appears to have run into what Bo Rothstein conceptualizes as a social trap: "a situation where individuals, groups or organisations are unable to cooperate owing to mutual distrust and lack of social capital, even where cooperation would benefit all." ${ }^{22}$ His notion of social traps builds upon the work of John Platt, who coined the concept in 1973 and identified various types of traps and reinforcement mechanisms. ${ }^{23}$ Among these are collective traps, prisoner's dilemma situations in which opposing parties tend to lock into either steady cooperation or steady conflict with each other. Rothstein points to the cognitive side of game theory and claims that human action is not a result of aloof, rational utility maximization but a strategic answer to anticipations of how other actors are going to act: "Efficient cooperation for common purposes comes about only if people trust that most other people will also choose to cooperate. ${ }^{24}$ In the absence of that trust, the social trap will slam shut, worsening the state of affairs for everyone. People are not perfectly informed, strictly rational, memory-free automatons; they cannot rationally decide to forget treacherous and deceitful behavior. What is perceived as a rational choice of action is entirely context dependent and builds upon prior experiences with other actors, socially, historically, and culturally. ${ }^{25}$ A related explanation of how social traps become stable is provided by Joel Bruckner and Jeffrey Z. Rubin's concept of entrapment: "a decision making process whereby individuals escalate their commitment to a previously chosen, though failing, course of action in order to 'make good' on prior investments." ${ }^{6}$ They fall into the "sunk cost fallacy" of failing to exclude already made, irretrievable investments when making decisions about future investments.

Like many other important concepts in human relations, trust is so multifaceted that any attempt to pin it down must leave out important aspects. At the core of the concept, however, is the relationship between an actor (A) who trusts and one who is trusted (B), and a willingness to become vulnerable to the behavior of others who can and may harm you. Russell Hardin wants us to include a third clause in the definition, the matter $(\mathrm{C})$ with regard to which one actor trusts another: trust is based on an assessment of the trustworthiness of the other in relation to a specific matter. ${ }^{27}$ In his encapsulated interest model of trust, Hardin more specifically claims that this assessment is based on the degree to which the interests of the trusting party are perceived to be encapsulated in the interests of the trusted party. This requires an 
ongoing relationship between the two; hence, in his conception, trust is strictly a person-to-person matter. Consequently, Hardin discards the concepts of generalized trust and trust in government as contradictions in terms.

However, as Rothstein points out, interpersonal trust relationships are governed by more than a self-interest-optimizing type of rationality, and interpersonal trust is also fundamentally different in character from institutional trust. ${ }^{28}$ Actors can be collectives as well as individuals, and, even though collectives must ultimately operate through the individual, there is a distinct difference between individual and collective rationality. It is a collective action to construct efficient institutions, that is, institutions that enable trust and confidence to be established in organizations and societies and that reduce the transaction costs between parties with a mutual interest in interacting in repeated sequences-even if they have conflicting interests in the specific transactions. Social capital is generated predominantly by the existence of universal political institutions, rather than by a vibrant civil society. Rothstein underscores the distinction between representative (policy making) and executive (policy implementing) democratic institutions. ${ }^{29}$ Whereas the main idea behind representational political institutions is partisanship and legitimate competition between conflicting interests, the main idea behind policy-implementing institutions is impartiality: fairness in procedures, equal treatment before the law, incorruptibility, non-discrimination, transparency, and so on. The latter are the institutions with which ordinary citizens have the most frequent contact, and the ones that generate social trust. In line with Metlay, Rothstein furthermore claims that people's experience of procedural justice matters as much as the final results of their interactions with public institutions. ${ }^{30}$ This way of viewing the causal mechanisms behind the production of social capital shifts the responsibility for creating a viable democratic society from citizens to political and implementing authorities, in line with the above conception of societal safety: the state holds the main responsibility. The core function of a vibrant civil society, then, we may instead see as that of a watchdog. Social distrust that builds on a realistic public assessment of government failures and the imperfections of democratic institutions is a healthy social-control mechanism that may be just as important as social trust to the well-functioning society. As Paul Slovic points out, it is when the balance between trust and distrust becomes badly skewed toward unreasonable distrust that systems start to malfunction. ${ }^{31}$

The risk and vulnerability aspects of trust help to explain why actors continue to be trapped. Using a risk perspective, I define trust as an investment of positive expectations in the future conduct of others with no a priori certainty that these expectations will be met and reciprocated rather than violated. To decide whether or not to opt for trust, people make a risk assessment of the situation; in so doing, they rely on their experience with other actors' previous behavior and/or on what they believe they know about them, while carefully monitoring their present behavior for clues to their future intentions. The knowledge people believe they have about other actors may be false, or may build on imperfect information, but they will still act upon it. Getting this risk assessment right is essential, as trust bestowed on the untrustworthy can be disastrous. When people have experienced the hard way precisely how disastrous it can be to trust people or institutions that cannot be trusted-whether ethnic others, government, or the international community-they may understandably become risk averse, letting suspicion and generalized distrust become their default option. Unfortunately, this may have a self-reinforcing effect. Toshio Yamagishi has found that low trusters are more often wrong in their 
assessments of the trustworthiness of others than high trusters are; when they are wrong, they become disappointed and react by withdrawing. As social intelligence is acquired through extensive interaction with others, this creates a vicious circle of distrust and insufficient social intelligence. ${ }^{32}$

\section{Getting Out of Social Traps}

In $\mathrm{BiH}$, the start-up capital for restoring lost trust, replacing the ethnic discourse with a human-rights discourse, and get out of the social trap is minimal. Nevertheless, if one can succeed in doing this within one institution-such as the MPI BiH-this success may have positive synergetic effects on the rest of society. Unfortunately, as there is no universal consensus on precisely how trust is produced, there exists no plain and unambiguous model for how to change a state of profound distrust into a state of reasonable trust, either at the interpersonal level or at the institutional level. Understanding the mechanisms of the social trap, as outlined above, may provide some guidance on finding the means to get out of such a trap. A few more aspects of trust, outlined below, may also come in useful: (1) two interrelated dichotomies, the conception of divisive/compatible ethnic entrepreneurs and that of bridging and bonding social capital; and (2) the concept of an asymmetry between trust and distrust, the notion that trust and formal control systems may be mutually reinforcing, and the possibility that trust may be both cause and effect.

In a study seeking to explain the rapid disintegration of the former Yugoslavia, Murat Somer defines divisive ethnic entrepreneurs as social-political entrepreneurs who advocate ethnic separation and exclusiveness, whereas compatible ethnic entrepreneurs are social-political entrepreneurs who advocate ethnic inclusiveness. ${ }^{33}$ They constantly compete to shift the public discourse through reputational cascade effects by mobilizing a critical mass of people to publicly embrace a specific discourse. Self-reinforcing reputational pressures on individuals who fail to conform may then create cascades of interdependent choices that move society from one equilibrium to another. The more people depend on their group membership for social status, the more responsive they will be to reputational pressures; the more one-sided the "group view" is, the more compelling it becomes to conform, and the more difficult it becomes to dissent. This may lead people to publicly either downplay or exaggerate their private beliefs. Somer defines public discourse as the collection of views, beliefs, values, and cultural-political preferences that people feel comfortable expressing publicly, where they cannot control their audience, and private discourse as those they feel comfortable expressing exclusively in familiar settings, where they can control their audience. Public expressions of trust in ethnic others may differ considerably from people's private trust; hence, the public discourse is a poor predictor of private trust in ethnic others. Still, people will draw their information about ethnic others from the public discourse, which will, over time, influence private levels of trust as well.

Somer claims that one's trust in ethnic others depends on one's level of involvement in cross-group relationships and on how beneficial that interethnic cooperation is. This brings us to Putnam's conception of the "bridging" (inclusive) and "bonding" (exclusive) dimensions of social capital that develop in social networks. ${ }^{34}$ Bridging social capital builds on weak ties transcending salient social cleavages; it facilitates self-organized networking and cooperation between people who are different from each other and promotes intergroup trust. However, not all self-organized civil groups produce intergroup trust. On the contrary, many networks develop from strong 
ties based on a common denominator, bonding their members in mutual support of each other, at the same time making them focus inward. This produces strong intragroup trust, but it may simultaneously produce strong intergroup distrust. Rothstein calls this the "Hell's Angels Syndrome." ${ }^{35}$ As Mark Baskin and Paula Pickering point out, it is also characteristic of extreme nationalist organizations that are "hierarchically structured, and willing to use violence to realize their exclusivist goals." 36 However, in an antagonistic ethnonationalistic environment, even less extreme monoethnic organizations split along ethnic lines may be in danger of developing exclusivist bonding social capital. According to Pickering, high levels of bonding social capital may threaten democracy by providing increased opportunities for divisive ethnic entrepreneurs. ${ }^{37}$ To support positive interethnic relations, organizations and institutions need to be ethnically diverse and acquaintance based, allow for individual norms, help people address practical matters that require repeated mutually dependent interaction, be rooted in local culture, and be difficult for people to avoid.

Slovic's asymmetry principle posits that trust is asymmetrically related to distrust in favor of the latter. ${ }^{38}$ First, the balance between trust and distrust is very easily disturbed because of certain psychological mechanisms. Trust is fragile, difficult to build, and easily destroyed; lost trust and confidence are even harder to restore than they are to build in the first place. Distrust, on the other hand, is easy to acquire and hard to overcome. Whereas trust building is incremental, the destruction of trust is instant. Second, distrust tends to reinforce and perpetuate itself, for two reasons: distrust tends to inhibit the kinds of contacts and experiences that are necessary to overcome distrust; and trust and distrust color our interpretations of events, thus reinforcing prior beliefs. As James G. March and Johan P. Olsen found in their study on organizational learning, distrust makes people avoid interaction with, oppose anything coming from, and tend to attribute all detrimental events to the distrusted actor. ${ }^{39}$ Third, trust-destroying events are more visible and carry greater weight than trust-building events; they are given more attention, both by individuals and by the media, than trust-building events, which are often fuzzy and indistinct. Trust-destroying news is also perceived as more credible than trust-building news. Finally, problematic events increase distrust far more than favorable events decrease it. It may be wise, then, to pay as much attention to distrust and trust-destroying factors as to trust and trust-building factors-if not more. If the point of departure is a state of distrust, lack of distrust may be a more realistic first goal to achieve than actual trust.

There are two main perspectives on the relationship between trust and formal control. One is the substitution perspective, which holds the two to be inversely related; the other is the complementary perspective, which holds them to be mutually reinforcing. The latter is gaining more and more support. Along with T.K. Das and Bing-Sheng Teng, ${ }^{40}$ Katinka Bijisma-Frankema and Ana Cristina Costa define formal control as "a regulatory process by which elements of a system are made more predictable through the establishment of standards in pursuit of some desired objective or state." It aims "at establishing task reliability by designing a set of rules that specify an actor's work and enforcing the actor's compliance with these prescribed standards." ${ }^{11}$ These authors claim that many of the benefits associated with trustopen communication and information exchange, belief in information received, increased perceptions of safety, commitment, mutual learning, attribution of positive motives, and heightened levels of cooperation and performance-can also be associated with modes of control. If the trust-control nexus really is positive, then ensuring task 
and behavior specifications and codification through formal control mechanisms may be a good starting point for building trust.

Finally, the fact that trust may be both cause and effect-a consequence as much as a precondition of what it produces ${ }^{42}$-means that the problem of trust can be approached from the angle of its supposed effects. If trust lubricates cooperation but cooperation also creates a basis for trust, and if the same applies to other positive outcomes attributed to trust, then reluctant or even compulsory cooperation, communication, and interaction may create a foundation from which trust can be built. Opinions very much to the same effect were also expressed by several of my interviewees, whose experience was that cooperation and interaction that they had only reluctantly agreed to had changed, over time, into what they perceived as true cooperation and mutual trust. They were convinced that the same would happen within the MPI BiH.

\section{Empirical Findings}

\section{Background: Trust Perceptions among the General Public in BiH}

In 2003, Peter Håkansson and Sarah Hargreaves conducted a comprehensive social trust survey across BiH for the Balkans Analysis Group in Sarajevo. ${ }^{43}$ Since 2000, the UNDP Early Warning System (UNDP EWS) in BiH, aiming to identify and predict crisis and conflict, has produced quarterly summaries of the results of public opinion polls, media and event monitoring, and official statistics. ${ }^{44}$ These surveys examine what can be seen as expressions of different kinds of trust, at and between different levels of society. In June 2005, UNDP EWS also conducted a special poll in connection with the conference Pathways to Reconciliation and Global Human Rights, surveying public opinions on transitional justice mechanisms. ${ }^{45}$ Together, these surveys provide an empirical backdrop for the topic discussed here and indicate the general amount of social capital present in $\mathrm{BiH}$ during the period under research.

From a generalized trust level of $26.9 \%$ found by the World Values Survey in 1998, Håkansson and Hargreaves found that in 2003 the level had dropped to only $14.5 \% .{ }^{46}$ Differences were huge across the eighteen regions of $\mathrm{BiH}$ examined, ranging from $1.4 \%$ in Una-Sana Canton to $61.9 \%$ in West-Herzegovina Canton-the one outlier that brings the overall level up to $14.5 \% .{ }^{47}$ Most regions had a trusting population far below this level. Many of the least trusting regions were those worst affected by the war (which are also those having the greatest problems with missing persons). Generalized trust was poorest among individuals aged between thirty-six and fifty in 2003 (which is also the age group making up the majority of surviving family members of missing persons). Not surprisingly, most people were particularized or partial trusters (i.e., turning their trust toward "their own community"). ${ }^{48}$ Respondents predominantly bestowed trust on family and relatives (ca. 85\%). On a descending scale, they trusted neighbors, other people well known to them, and people of their own nationality. Least trusted were people of a different nationality or with a different way of life. However, respondents who trusted some or all/most of their own nationality would also trust some or all/most ethnic others. Still, $20 \%$ trusted no ethnic others, and the category of outright distrusters-those who trust no one at all-was also disturbingly large. A strong correlation was found between spending time with ethnic others and trusting ethnic others. Even so, 37\% seldom or never spent time with ethnic others; among those who trusted no ethnic others, the figure was $75 \%$. 
According to the UNDP EWS special poll in 2005, about $60 \%$ of respondents had felt their lives threatened during the war. For about 50\%, the war still had a huge negative impact on their everyday lives. About half of respondents considered everyone victims of the war to a certain extent; Serbs held this opinion more often than Bosniaks or Croats did. A great majority were in favor of criminal prosecution (96.7\%), either of anyone "who caused unjustifiable harm to others during the war" (64.9\%) or only of actual war criminals. A significant majority also believed that war criminals and war crime suspects "should not work in public institutions or be allowed to influence their operations" (72\%). Still, most respondents had no great faith in the ability of either the International Criminal Tribunal for the Former Yugoslavia (ICTY) or the domestic courts to secure criminal accountability.

With respect to institutional trust in general, Håkansson and Hargreaves found that trust in government was approximately 50\% at both state and entity levels and about $60 \%$ at the municipal level; respondents had somewhat more trust in the executive bodies, the courts, the police, and the army. The 2003 EWS surveys were generally in agreement with the Social Trust Survey. ${ }^{49}$ Since then, institutional trust has steadily decreased, reaching an all time low by September 2005; thereafter there has been a constant state of flux. However, even the highest peak of approval, by the end of 2006, did not reach 2003 levels. This trend seems inversely correlated with a steadily growing conviction that officials of the same institutions are either very or quite considerably corrupt. By September 2007, about two-thirds of respondents believed the same applied to governance structures at all levels, as well as to the police and the courts (which got the "best" score, ca. 50\%). International institutions such as the Office of the High Representative (OHR), ${ }^{50}$ the Organization for Security and Cooperation in Europe (OSCE), the UNDP itself, and the European Union have fared only somewhat better on both variables. In general, Bosniaks and Croats approved of state-level governance structures more than Serbs did until the end of 2005, when the pattern reversed. Bosniaks and Serbs also generally approve more of the governance structures of their "own" entity than of those in the "other" entity; Croats fall between the two with respect to both entities. Although two-thirds to three-quarters of respondents basically or entirely disagree that "only ethnic parties can secure the fundamental interests of the constituent peoples they represent," people continue to vote ethnonationalist parties into power. Those who vote, that is-voter turnout for the general elections held in October 2002 and October 2006 was only about 50-55\%. It took six months to form the legislature after the 2002 elections, and four-and-a-half months in 2006, which may be regarded as symptomatic of the general inefficiency of political decision-making processes in $\mathrm{BiH}$. At any given time, apart from minor surges of optimism immediately following elections, at least half of respondents believe that the political situation is only getting worse, and at least one-fifth fear that war will break out again if international security forces are withdrawn.

The overall pattern is thus rather discouraging: trust of all kinds is low and has decreased since war's end, and the ethnic discourse, fueled by nationalistic, polarizing partisan politics, is still the dominant public discourse.

\section{Institutional Framework: The Law on Missing Persons of $\mathrm{BiH}$}

Supported by international organizations, notably the ICMP and the International Committee of the Red Cross (ICRC), families of missing persons have continually pressed for government to accept its responsibility toward the missing and their families. At the end of 2002, their persistence led the $\mathrm{BiH}$ Council of Ministers to 
charge the Ministry of Human Rights and Refugees (MHRR) with drafting a domestic Law on Missing Persons. In March 2003, the ministry organized a roundtable discussion with family-association representatives, who were also consulted throughout the drafting process. A working group was established in May that included representatives from the MHRR, the entity-level commissions on missing persons, the entity and Brčko District governments, the ICMP, and the ICRC. ${ }^{51}$ The resulting law was passed by the $\mathrm{BiH}$ legislative bodies in October 2004 and entered into force on 9 November $2004 .^{52}$

The Law on Missing Persons addresses the social and economic rights of family members of missing persons. The core right is the right to know and the related obligation to provide information on the part of the state and entity authorities. The right to know the fate and whereabouts of a missing person is codified by the Geneva Conventions (1949) and their Additional Protocols (1977). ${ }^{53}$ In a study by the Office of the High Commissioner on Human Rights (OHCHR), this right has additionally been declared an inalienable, non-derogable, and autonomous human right, linked to the duty of the state to protect and guarantee human rights, conduct effective investigations, and guarantee effective remedy and reparations. ${ }^{54}$ This right is now also codified in the BiH Law on Missing Persons, which-by including families' right to know the circumstances, the cause of death, and the place of burial of a missing person proved dead and their right to have the mortal remains of their relatives returned to them actually goes further than international humanitarian law requires. In addition, anybody, including foreign citizens, can file a tracing request. ${ }^{55}$ Other rights of importance are the right to financial support and the related establishment of a fund for support to families of missing persons; family members' right to temporarily dispose of the property of missing persons, even if the missing has not been proclaimed dead; and a guarantee the tracing process will not be concluded until the mortal remains have been found. ${ }^{56}$

The implementation of international law into domestic law in itself increases societal safety, providing families with much stronger statutory protection and placing much more concrete obligations on the state than would mere ratification of international law. Although trust cannot be legislated into existence, law is an important first step in fostering trust in institutions. Laws are normative; they show the intentions of lawmakers and promise a certain level of commitment on their part. In the $\mathrm{BiH}$ case, the law was not forced or imposed from the outside but resulted from a negotiation process among domestic governance structures that have had great difficulty in cooperating on other reforms. The process was conducted under the auspices of a domestic political institution; it included the top officials of the executive bodies concerned, the entity-level commissions on missing persons; and, although definitely a top-down process, it included extensive public participation by the primary stakeholders, the families of missing persons. ${ }^{57}$ From a social-safety perspective, it is also important that the law so clearly stresses the state's obligations as duty holder and emphasizes the obligations of the so-called relevant authorities at the state, entity, cantonal, and municipal levels to provide families and responsible institutions with all available information and necessary assistance required to resolve the issue. These bodies are furthermore instructed to cooperate unconditionally both amongst themselves and with the ICMP, the MPI BiH, the ICRC, and the BiH Red Cross Society. ${ }^{58}$ Although it took years to get the lawmaking process started, once underway it was not excessively time consuming and should, overall, be deemed rather successful: on important principles, by and large, the parties have agreed without 
major problems. Finally, via ICRC, the BiH Law on Missing Persons, a historical first, may also come to influence societal safety in other countries struggling to deal with large numbers of missing persons. ${ }^{59}$

\section{Challenges at the Institutional Level}

In order to make an impact, law needs to be implemented, operationalized, and enforced-a far more difficult task than drafting the law itself, as it requires a vigor and capacity that seem not to be present to the same extent as were the good intentions. Part of the problem of implementing decisions in top-down processes in hierarchical systems is to make them filter down the system from the strategic policymaking level at the "blunt end" to the operational level at the "sharp end" of the system. ${ }^{60}$ At each level, there will be several actors and stakeholders who have a certain degree of freedom to make choices about the means of, and time for, action and who will tend to meet local problems with local solutions. This applies particularly to so complex a public management system as exists in $\mathrm{BiH}$, where the individual parts of the system are highly autonomous and are influenced to different degrees by the ethnic discourse in society. Getting actors at various levels to interact dynamically requires measures to secure information flow and feedback mechanisms between them; but first and foremost it requires that they actually know about the decisions they are expected to operationalize. Considering the emphasis laid on the obligations of "relevant authorities" at all levels, there is reason to ask how well aware "sharp end" authorities, public officials, and civil servants are of the demands made on them by the Law on Missing Persons. In 2006, in cooperation with ICMP, ICRC, OHCHR, and the $\mathrm{BiH}$ Centre for Free Access to Information (CSPI), the MHRR created a Guide for Families of Missing Persons on the application of the law, in order to make it easier for them to understand and exercise their rights. ${ }^{61}$ Family-association representatives, however, report mixed experiences with the usefulness of this guide vis-à-vis the authorities. They point to a frequent lack of knowledge at all levels, including the state level, about the very existence of the law, and suggest that a similar guide be created for the relevant authorities, to raise their awareness about the law itself, what the families need, and their own obligations in this connection.

\section{Organizational Framework: The Missing Persons Institute of $\mathrm{BiH}$}

Originally proposed in 1998, a Missing Persons Institute was registered by the ICMP with the Cantonal Court in Sarajevo in August 2000, in connection with the responsibility for coordinating the Joint Exhumation Process (JEP) then being handed over by the OHR. ${ }^{62}$ In June 2003, the BiH presidency agreed that the state should become a co-founder and asked the Council of Ministers to establish a protocol on a BiH Missing Persons Institute. In December, a working group led by the MHRR and including representatives of the entity and Brčko District governments and of the ICMP was charged with drafting the protocol. Representatives of the Federal Commission, the RS Office, and the ICRC had observer status. In December 2004, families of missing persons were informed of the status of the implementation of the MPI; their representatives submitted their comments in mid-January 2005. An agreed-upon version of the protocol was presented to the Council of Minister in February and harmonized by the co-founders and the entity and Brčko District representatives in April. ${ }^{63}$ Approved by the Council of Ministers on 5 August 2005, the "Agreement on Assuming the Role of Co-Founders of the Missing Persons institute of Bosnia and Herzegovina" was officially signed by the co-founders on 30 August, the 


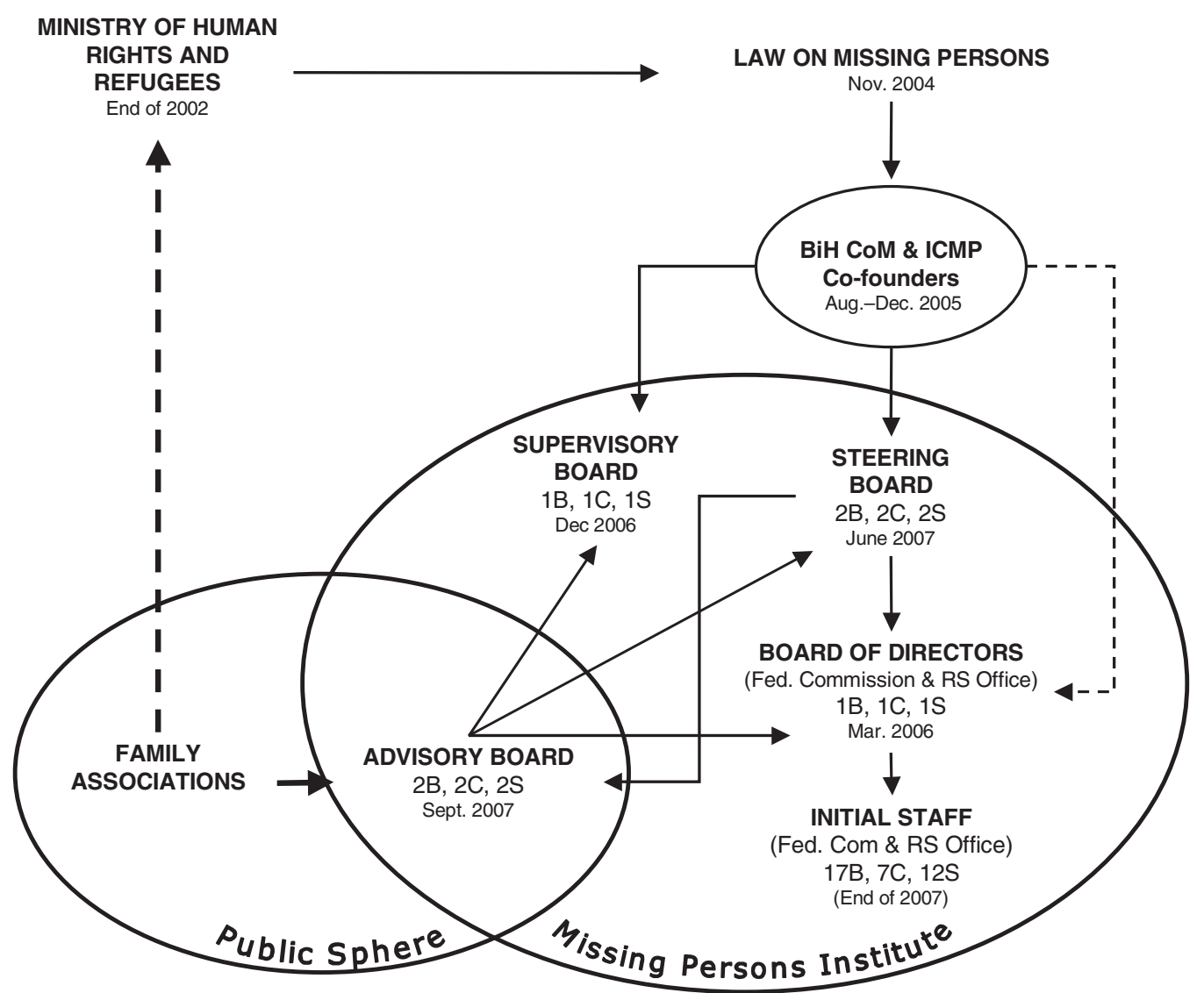

Figure 1. The organizational structure of the Missing Persons Institute of Bosnia and Herzegovina, including chronology of the implementation process

International Day of the Disappeared. ${ }^{64}$ The agreement was ratified on 28 December, and the implementation of the MPI $\mathrm{BiH}$ as an independent state-level institution began with the agreement's publication in the BiH Official Gazette on 29 December $2005 .^{65}$

The organizational structure of the MPI BiH is fairly complicated, consisting of one structure for the permanent organization and one for a transitional phase (see Figure 1). The permanent organization includes three management bodies-a threemember Supervisory Board, a six-member Steering Board, and a three-member Board of Directors-and the staff. The staff report to the Board of Directors, which reports to the Steering Board, which reports to the founders; the Supervisory Board is a reviewing body that reports to the two other management boards and to the founders. In addition, an Advisory Board consisting of six family-association representatives advises the management bodies and monitors the work of the MPI; members of the Advisory Board have observer status on the Steering Board. The founders appoint members of the Supervisory Board and the Steering Board by consensus, nominating three members each to the Steering Board, which then appoints the Board of Directors and the Advisory Board. Advisory Board members are nominated by $\mathrm{BiH}$ family associations. All management-board appointments are to be based on professional 
qualifications pursuant to an open public competition. In the case of the Steering Board and the Supervisory Board, a ranking of candidates is made by a selection committee appointed by the founders in consultation with entity and Brčko District governments; in the case of the Board of Directors, this process is carried out by the Steering Board. All board members' terms are fixed at four years. Members of the management boards may not, and Advisory Board members cannot, be reappointed. All board-member appointments must fulfill the constitutional principle of equal ethnic representation of the constituent peoples of $\mathrm{BiH}$ (Bosniaks, Bosnian Croats, and Bosnian Serbs). Chairs of the three management boards may not belong to the same constituent people; the chair of the Board of Directors must rotate every eight months, whereas no such requirements are made of the chairs of the two other boards. All boards are to make decisions by consensus, requiring a minimum quorum of one representative of each constituent people.

As a means of transition, the two co-chairs of the Federal Commission and the director of the RS Office were to be appointed to the initial MPI Board of Directors for a two-year term, after which the open competition for these positions would be held. This was to happen within ninety days of the signing of the agreement (i.e., the end of November 2005). ${ }^{66}$ Their staff were to be transferred to form the initial staff of the MPI $\mathrm{BiH}$. Bylaws to make possible the transfer of authority and competencies from the entity-level commissions were to be in place by end of June 2006, and these commissions were to cease their work by end of September $2006 .{ }^{67}$ No other strict deadlines were set in the agreement, but by necessity the Steering Board would have to be in place by the same time for the MPI BiH to begin functioning at full capacity. The ICMP was to continue providing technical and expert assistance, but with time the intention was to hand over equipment and other assets, apart from the DNA laboratories, and then pull out by the end of $2007 .^{68}$

The initial Board of Directors was appointed at the end of February 2006. ${ }^{69}$ Bylaws on the transfer of authority and competencies were adopted in June (RS, amended in October) and September (Federation of $\mathrm{BiH}$ ) 2006, but their entry into force depended on the full establishment of the MPI. ${ }^{70}$ Vacancy notices for the Steering Board and the Supervisory Board were issued in August 2006; although the one for the Supervisory Board had to be reissued in September because there were too few applicants, members of the Supervisory Board were appointed in December 2006. In contrast, despite the fact that a ranking of twenty-six qualified candidates was forwarded to the co-founders by the end of September 2006, members of the Steering Board were not appointed until June 2007. ${ }^{71}$ They formally appointed the Advisory Board members in September 2007, and at the end of November 2007 the BiH Council of Ministers finally adopted the steering documents needed for the MPI BiH to become operational $^{72}$ - more than seven years after the original founding of the MPI by the ICMP, four years after it was agreed that it should become a $\mathrm{BiH}$ institution, three years after the Law on Missing Persons came into force, and more than a full year behind the schedule laid out by the agreement.

\section{Risks to Institutional Trust Building Produced by Role Conflicts}

The MPI BiH nearly did not get off the ground in the first place, as a result of major disagreements about the method of appointing the initial Board of Directors and whether or not its members should be exempted from article 5 of the Law on Missing Persons, whose application to implementation of the MPI the agreement specifically underscores. ${ }^{73}$ This article states that "Officials with duties related to the tracing of 
missing persons cannot carry out this duty if they are members of steering and other boards, or executive bodies, of political parties, or if they are politically engaged representatives, and must not follow political party instructions." ${ }^{74}$ This became an issue because in order to secure transfer of experience and not lose momentum, it seemed natural to let the heads of the former entity-level commissions initially head the MPI BiH as well. However, the Bosniak co-chair of the Federal Commission, Amor Mašović, was and is a delegate of the Bosniak Democratic Action Party (SDA) to the House of Peoples of the Parliament of the Federation of BiH. ${ }^{75}$ Republika Srpska (RS) politicians, the RS Office, and RS missing-persons family associations strongly opposed Mašović's candidature, arguing partly on the principle that it was against both the Law on Missing Persons and the Law on Conflicts of Interest and would bring ethnic politics directly into a process that needs to be depoliticized, ${ }^{76}$ and partly ad hominem. ${ }^{77}$ Mašović himself has chosen not to resign, either from his political position or from the MPI BiH, claiming that there is no conflict of interest. The RS organizations, however, have not been willing to leave the matter as it was temporarily settled, by giving the issue a two-year respite, but have routinely repeated their principled argument in almost every statement to the press about the MPI BiH. As the term of the initial Board of Directors expired at the end of February 2008, the issue was to be one of the first challenges presented to the Steering Board. ${ }^{78}$ With respect to the principle of the matter, their worry is absolutely legitimate: the role of a politician and the role of a public official are by definition incompatible and cannot be executed simultaneously. Politicians are supposed to have agendas biased toward specific interests; public officials are supposed to administer political resolutions impartially, irrespective of their personal political preferences. Thus, from an institutional trust perspective, the situation is unfortunate, to say the least.

Another mixing of roles that may have set back the building of institutional trust involves the members of the initial Board of Directors and the fact that there has been no clear distinction between their roles as heads of their respective entity-level commissions and their roles as directors of the MPI BiH. People depending on the public administration should not have to wonder who they are dealing with at any given time; some predictability is required to enable people to trust their institutions and public officials. It is confusing, and produces uncertainty about the whole process, when the same persons make statements sometimes in one capacity and sometimes in another. The limbo in which the initial Board of Directors found itself for more than a year, between the appointment of its members and the appointment of the Steering Board-and specifically after October 2006, when the entity-level commissions did not cease to exist as planned-seems to have further exacerbated this situation. Rather than appearing in the public discourse unanimously as a collegium of directors, the Bosniak and Serb directors especially continued to predominantly represent their respective entity-level commissions, opposing or criticizing each other publicly even as late as November $2007 .{ }^{79}$ However, only these incidents of non-cooperation made the news, whereas their cooperation on all the bureaucratic tasks of preparing and agreeing on system designs, rules and regulations, plans and budgets-essential to making the organization work as an efficient, universal institution-simply has not been of interest to the media. The same applies, of course, to the Working Group on Implementation of the Law on Missing Persons, the Expert Group on Central Records of Missing Persons, and the Expert Group on Excavation and Examination of Mortal Remains, in all of which they have participated. ${ }^{80}$ 


\section{An Inherent Structural Dilemma: The Embedded Ethnic Discourse}

As is apparent from even a glance at the organizational structure of the $\mathrm{BiH} \mathrm{MPI}$, the ethnic discourse is incorporated in various ways into the organization itself. The structure closely follows the governance principles laid down in the consociational constitution, or group-based power-sharing system, of $\mathrm{BiH}$, which was part of the Dayton Peace Agreement. ${ }^{81}$ From Hardin's trust perspective, such a system may be characterized as being based on the collective presumption that the interests of one ethnic group cannot possibly be encapsulated in the interests of other ethnic groupshence the need for proportionality in group representation and the demand for consensus at every possible decision-making level. As Sumantra Bose points out, this kind of system is essentially discriminatory, in that it recognizes some collective identities to the exclusion of other possible identities and institutionally entrenches the cleavages and divisions based on these identities. ${ }^{82}$ Furthermore, it prevents the development of new collective identities. Such a system can work only if the will and capacity for cooperation exist at the highest levels.

In $\mathrm{BiH}$, access to power and position is restricted almost entirely to the so-called constituent peoples-Bosniaks, Bosnian Croats, and Bosnian Serbs-although some access is also granted to the category of "others." There exists no formal identity category for those who want to identify themselves simply as Bosnian-Herzegovians, and those $\mathrm{BiH}$ citizens who lost their former national identity as Yugoslavs have no other option but to conform to the existing system of ethnic identities. The organizational structure of $\mathrm{MPI} \mathrm{BiH}$, however, includes no representation of the "others" category in its organizational structure. This became a factor in delaying the appointment of the Steering Board.

Arguably, the selection committee began its work a little late to get the members of the Steering Board appointed in good time before the October 2006 deadline, which happened to coincide with the general elections. The delay in forming the legislature after the election further postponed the process, and meant that the ICMP had no real co-founding partner for an extended period. Pressed hard-for example, at a meeting on 8 December 2006, organized by the MHRR and the ICMP and attended by family-association representatives, the Board of Directors, and the ICRC $^{83}$ - the outgoing Council of Ministers decided on their three nominees to the Steering Board on 28 December 2006, at which point the ICMP also made public the names of their three candidates. ${ }^{84}$ Because three of the candidates in the "Serb" group were of mixed ethnicity, the Council of Ministers did not, as agreed, choose their candidates from the top of the ranking list. Publishing the names before having officially agreed on the appointments was arguably a mistake in terms of intergroup trust building. The person who had moved up the ladder to a nomination, the president of the Union of Associations of Families of Missing and Captured Persons of Republika Srpska in BiH (RS Union), immediately became the subject of harsh public dispute. For example, rather than perceiving her nomination as an opportunity to place an ally on the Steering Board, the Srebrenica family associations strongly opposed her candidature, claiming that she showed no respect for the victims of other nationalities-exactly the same type of claim that Serb umbrella organizations make about other nationalities' treatment of Serb victims. ${ }^{85}$ By the end of May 2007, the issue remained unresolved. Despite a proposal from the Ministry of Human Rights and Refugees to appoint the three highest-ranked and the three second-highest-ranked candidates-as was agreed from the beginning, and became the solution in the end-other ministers requested that the selection process 
be annulled and a new one be undertaken. ${ }^{86}$ Had this happened, it would probably have been a trust-building catastrophe.

\section{The Right Holders: The Missing and Their Surviving Family Members}

According to the Law on Missing Persons, a missing person is a person who, due to the armed conflict in former Yugoslavia, went missing in or from $\mathrm{BiH}$ between 30 April 1991 and 14 February 1996, ${ }^{87}$ remains unaccounted for, and at the time of disappearance was either a civilian or a member of the armed forces. According to the ICRC, about $92 \%$ of such persons were male. ${ }^{88}$ Today, fourteen years after war's end, following the recovery of thousands of missing persons' mortal remains from mass graves, single graves, forest floors, and other environments, it is highly unlikely that any significant number of the missing will be found alive.

As of today, nobody knows the exact number of missing persons. Until the ICRC and ICMP databases are fully correlated, there is no way to determine exactly who is in both and who is only in one or the other of these databases. Still others may figure only on the lists of the former entity-level commissions, other entity-level authorities, or family associations. It is unlikely, however, that anyone would falsely uphold a tracing request for years, or would provide blood for identification of their missing family members without reason. Therefore, the number of ICRC tracing requests and the number of blood samples donated to ICMP represent a reliable basis for calculating the minimum number of missing persons. ${ }^{89}$ As of 28 March 2008, 67,966 blood relatives had donated blood samples to the ICMP representing 23,022 missing individuals. ${ }^{90}$ Through matching of DNA profiles obtained from bone samples with DNA profiles obtained from blood samples, 11,230 individuals had been identified. ${ }^{91}$ At the same time, the number of unique DNA profiles obtained from bone samples showed that 14,345 individuals were represented among the mortal remains. This means that 3,115 missing persons had been found, recovered, and DNA-profiled for whom there were no matching references, bringing the minimum number of the missing up to 26,137 . The ICMP's estimate of about 30,000 missing persons in total is thus a realistic figure. ${ }^{92}$

From a societal-safety perspective, the number of concern is not so much the number of missing persons as the number of their surviving relatives. They are the ones to whom the state now has a primary obligation to protect their life and health and to meet their basic requirements. The state can restore missing persons' dignity as human beings, which in itself is a strong signal of societal safety to other members of society; but it cannot give them back their life and health. It goes without saying that the closest family members of the missing-whether blood relatives or affiliated through marriage or cohabitation, the right holders according to the Law on Missing Persons ${ }^{93}$-are the most deeply and directly affected members of society. Based on the DNA statistics, on average we can count on three living blood relatives for each missing person; adding those who are not related by blood, we will probably arrive at close to 100,000 people whose lives have been turned completely upside down. Not only were they bereaved of their loved ones, often under severely traumatic circumstances, but their social and economic life situation also became highly insecure and unstable, as in most cases the missing person was the main provider of the family. Because of the uncertain civil status of their missing relative, their own civil status remained unsettled. Until the passage of the Law on Missing Persons, problems concerning property, insurance, inheritance, and so on could not be resolved unless family 
members were willing to proclaim their missing relatives dead and let the tracing process stop.

\section{Associations of Families of Missing Persons}

Among so many people, we may safely assume that there will be all sorts of personalities, with different capacities and coping capabilities. Admirably many have found within themselves the resources to address their extremely difficult situation and the stamina to continue doing so over many years, despite the magnitude of the problems they have had to address and the emotional exhaustion and frustration this causes. In order to search for their missing family members and pursue their legal and human rights, approximately 40,000 family members of missing persons have organized themselves into more than sixty family associations, almost all of them registered NGOs. ${ }^{94}$ Because geographically specific events have typically been their organizing principle, these associations are all mono-ethnic. Apart from one association of families of missing Roma people, based in Tuzla and formed in 2003, all are made up of families of missing Bosniaks, Croats, or Serbs. The first Bosniak and Croat family associations were formed during the war, beginning in 1993; many were formed in 1996, when Serb families also began associating under the umbrella of the Republican Board of Families of Missing Persons (RS Board), a sub-organization of the Republican Organization of Killed and Detained Soldiers and Missing Persons of Republika Srpska (RS Organization). In 2002, a group of eight family associations broke away from the RS Organization and created their own umbrella organization, the Union of Associations of Families of Missing and Captured Persons of Republika Srpska in BiH (RS Union). A year before, in 2001, twelve Bosniak family associations had also created an umbrella organization, the Union of Bosniak Associations of Families of Captured and Missing Persons in Bosnia and Herzegovina (Bosniak Union), from which one association, the Association of Women from Prijedor 'Izvor,' later broke away. A number of other family associations-Serb, Bosniak, and Croatare free-standing, the Croat associations, however, cooperating as if an umbrella organization existed. Also the family associations of victims of the Srebrenica Genocide are free-standing but bound together in a non-formalized cluster, at the core of which are the Women of Srebrenica, the Mothers of Srebrenica and Žepa Enclaves, the Srebrenica Mothers, and the Mothers of Srebrenica and Podrinje.

In 1998, the ICMP began actively supporting family associations in their efforts to advocate for their interests, through activities pertaining to four main areas: empowerment, networking, awareness building, and promotion of mutual understanding-for example, by providing grants for various activities initiated by the family associations themselves. Over the years, the ICMP's Civil Society Initiatives Department has organized a large number of workshops, seminars, and roundtables for family-association representatives of both mono-ethnic groups and groups of mixed ethnicity, both in $\mathrm{BiH}$ and across the former Yugoslavia. $\mathrm{BiH}$ family associations have participated in the annual Regional Networking Conferences on the Issue of Missing Persons in the Former Yugoslavia, organized by the ICMP since 1998, at which familyassociation representatives have come together to discuss common issues and had the opportunity to directly address invited representatives of their respective responsible national authorities. At the eighth such conference in 2005, family-association representatives decided to form a regional coordination board in order to jointly promote their common goals. This board constitutes an additional basis for developing bridging social capital and for strengthening the human-rights discourse. However, a 
sub-regional coordination board of Serb family associations, created simultaneously to make this coordination process easier, instead developed strong bonding social capital based on the ethnic discourse. On a couple of occasions this has led to their withdrawing from planned joint activities, in consequence of which they have lost the trust of other family-association representatives. ${ }^{95}$

In $\mathrm{BiH}$, family-association representatives have been dissatisfied with the status and position given to the Advisory Board in the organizational structure of the MPI $\mathrm{BiH}$, which they perceive as "their" institute. They wanted the Advisory Board to be appointed by the founders, so as to be on par with the Steering Board; and if not on par, they wanted, as a minimum, more than just an observer role on the Steering Board. They wanted to have real decision-making power, rather than, in the words of one representative, "only give recommendations, suggestions, advice, and proposals, [which] doesn't oblige anyone to accept it." They feel a strong need to be in control, derived from their distrust in the ability and will of the authorities to cooperate in the interests of all nationalities. They consider themselves much better at cooperating than the responsible authorities, and more willing to embrace the discourse of human rights.

There are, however, limits to the public participation of right-holder groups. As right holders, families of missing persons cannot be charged with duty-holder obligations; they cannot be made responsible for providing themselves with their own rights. From the point of view of the implementing authorities, the families have been included as far as is feasible throughout the drafting and implementation process. These authorities perceive the formal role that family representatives will have, through the Advisory Board, as important and far-reaching; ${ }^{96}$ "the Advisory Board will monitor the work of the Institute and will essentially be its watchdog." "97 This role may be a challenge in itself. Given the requirement of reaching decisions by consensus, members of the Advisory Board may be expected to act as a unit; furthermore, they will have to represent not just the associations or umbrella organizations from which they are recruited but all families and family associations of missing persons in $\mathrm{BiH}$ who have no direct representation on the Advisory Board. So far, they have no organizational system for obtaining information and opinions from these other associations, or vice versa. There must have been talk at some point of forming a joint $\mathrm{BiH}$ union of family associations, however, since in 2005 the president of the RS Union told a newspaper that her organization did not agree with establishing such a body. ${ }^{98}$ Thus, apart from the interim Advisory Board, which existed for some years before it was officially appointed in autumn 2007, there has been no systematic attempt among the families to coordinate a common strategy toward the authorities.

\section{Challenges to the Discourse of Human Rights among Families of Missing Persons}

All family-association representatives I have interviewed agree that there is an ethnic polarization among the family associations. One interviewee said that the respect and understanding for one another that family-association representatives had gained by interacting at the leadership level was fragile and had not filtered down to ordinary association members. No multi-ethnic family associations exist, either locally or nationally. In fact, in many places several family associations exist side by side without trying to join forces, although some do cooperate on a minor scale. ${ }^{99}$ Their monoethnicity, the nature of the specific events that made them associate, their sometimes strongly conflicting interests, the creation and fractioning of umbrella organizations, 
and all the emotions these circumstances evoke make family associations prone to develop bonding social capital based on the ethnic discourse. In spite of this, they keep coming back to each other, keep trying to settle hurt feelings, keep trying to cooperate and develop bridging social capital. There has been great progress, but there have also been major setbacks because rationality, in the common sense of the word, has frequently been overruled by emotional reactions. These reactions should not be seen as simply irrational; there is a rationale and logic behind them that is difficult to overcome with reason. I therefore prefer to conceptualize this as emotional rationality, to put it on par with other kinds of rationality.

The majority of surviving family members are women, many of whom, before the war, were housewives and led traditional women lives, their main responsibility being to provide for well-being within the family. This applies across ethnicities to all family associations, but a number of Bosniak family associations, especially the Srebrenica-related ones, have turned it into an asset, achieving moral authority for their case by stressing their roles as women, as wives and mothers of innocent civilians, in the names of their organizations and in their way of presenting themselves as victims. ${ }^{100}$ The various familial relations of surviving relatives to their missing family members, and whether the missing person was a (by definition innocent) civilian or a (implicitly not so innocent) soldier, produces certain status differences that are emotionally hard to overcome. However, whereas dying in battle is an occupational risk of being a soldier, going missing is not. Relatives of missing soldiers do not suffer from the loss of a soldier but from the loss of a husband, father, son, or brother; these families have the same right to know the fate and whereabouts of their loved ones as anyone else, which is exactly why the term missing person, in the Law on Missing Persons, includes all categories of persons unaccounted for, civilians and soldiers alike. ${ }^{101}$

That the missing are unaccounted for as the result of a criminal act also creates status differences among family members. The criminal act in question may vary from the gravest of crimes-genocide, crimes against humanity, war crimes-to the lesser crime of failing to secure and provide information on the identity, fate, and burial place of a combatant. Because the perpetrators are ethnic others, and because the crimes, in terms of severity and magnitude, are unequally distributed across ethnicities, the problem acquires a collective dimension, producing status differences between ethnic groups as well as among family associations. The collective identity easily comes to overpower the individual identity, the ethnic discourse to overrule the human-rights discourse. In the legal system, these crimes are hierarchically categorized according to their severity, and punishment is to be measured out proportionately. Family members' right to know cannot be categorized in the same way; it applies equally to all family members, regardless of which crime is suspected to have led to the disappearance. This is an important notion that is nevertheless very hard to cope with emotionally-especially because families are pursuing not only truth about what happened but also criminal justice for their victims, and because establishing this truth feeds into the pursuit of justice. It is important to remember that exhumations are carried out under the jurisdiction of the courts, and that the exhumation site is in fact a crime scene. This applies even when the primary purpose is to recover mortal remains for identification and repatriation and not to provide evidence for court procedures.

The lack of an explicitly formulated common strategy based on a human-rights discourse puts family associations in danger of being sucked into politics and being 
exploited by divisive ethnic entrepreneurs, particularly because most family members have no pre-war experience of organizational life in terms of dealing either with authorities or with the media. They have had to go through a steep learning curve. To raise public awareness of their specific case, they all depend on media attention, which they attract to different degrees. Croat family associations and Bosniak family associations other than the Srebrenica associations seem to attract the least, but most sober, attention, predominantly in connection with exhumations, burials, anniversaries, commemorations, and court procedures. Most media exposed, and consequently most in danger of being carried away by the ethnic discourse of external actors, are the Srebrenica and RS family associations.

\section{Clashes between Different Perceptions of Reality: The Identification Process}

The ICMP made its first DNA match between blood and bone samples in November 2001. It has since perfected its DNA identification methods, which are now state of the art, incredibly time efficient and with increasingly more capacity. As odontology cannot be used for identification in $\mathrm{BiH}$ because of a lack of dental records, identification was originally based predominantly on anthropological evidence in combination with recognition of clothes and personal items by family members. The number of identifications based on these methods would have remained modest relative to the total number of missing persons; unidentified corpses had already begun to pile up, and the situation required a resolution. Without ICMP's unique research and development achievements with the DNA method, which would not have been possible in earlier days, resolving the missing persons issue would have been a completely different matter, requiring completely different solutions to almost all aspects of the issue.

However, DNA analysts are scientists, not magicians. They cannot provide answers unless they have all the necessary variables. Some problems, such as not being able to extract quality DNA material from submitted bone samples, may be solved scientifically. Most problems, however, seem to be caused by distrust arising out of a classical expert-layperson dilemma, the experts having difficulty in getting information across to lay people who perceive things from their own point of view, intricately mixed with the prevailing ethnic discourse. The lack of matching blood references for the 3,115 found, recovered, and DNA-profiled missing persons mentioned above is a huge problem. To some extent, it may simply be that there are no surviving relatives, or that only non-genetically related family members have survived. Unfortunately, however, despite intensive blood collection campaigns and public appeals, the major problem seems to be that blood relatives fail, or refuse, to provide blood samples for identification purposes. One reason may be the emotional dilemma involved-donating a blood sample may be perceived as equivalent to giving up hope of one's missing relatives being still alive. Another reason, however, is that people do not understand two essential variables of the process: the necessity of having the right combination of blood samples in relation to the submitted bone samples to make a DNA match, and the fact that there is a proportionality between the number of samples submitted and the number of identifications obtained-one of the topics discussed at both the Eighth and Ninth Regional Family Association Networking Conferences in 2005 and 2006.

The lack of matching reference blood samples is a problem among all ethnonational groups. ${ }^{102}$ However, distrust seems most pronounced among RS families. Although the 
DNA-processing system has been carefully designed to be absolutely blind, and despite efforts to explain the process and the system, Serb family-association representatives suspect it of being ethnically biased and of deliberately discriminating against them. They argue that fewer DNA matching reports are received by Serbs and Croats than by Bosniaks, that Srebrenica victims are prioritized (5,332 identifications made as of 28 March 2008), and that many family members who donated blood samples years ago have not yet received any answers on the fate of their missing relatives. Incidents such as the case of the husband of the president of the RS Board-exchanged and buried unidentified in 1994, exhumed and stored in a Republika Srpska facility since 1998, and not identified until spring 2007-have not helped to produce more trust in the process. ${ }^{103}$ As the problems in this case seem to have resulted mostly from a lack of transparency and coordination among different agencies performing various steps in the process, it could have shifted attitudes in favor of the MPI BiH, which is supposed to streamline the process in the future by applying precise rules and policies regulating the exhumation, examination, and identification processes. However, the ethnic discourse seems to be too strong. Despite the clear public attitude of the Serb codirector of the MPI $\mathrm{BiH}$ that the institute will be of benefit in the recovery and identification of Serb victims, the president of the RS Organization and former head of the RS Office wants to "return the entire $\mathrm{BiH}$ MPI establishment to its very beginning." 104

Considering the former argument, first of all, in total there are simply fewer missing Serbs and Croats than missing Bosniaks. Furthermore, so far the search and recovery process has been ethnically divided, with the Federal Commission responsible for Bosniak and Croat missing persons and the RS Office for Serb missing persons. The ratio of bone samples submitted by the RS Office to those submitted by the Federal Commission (about 1:11) does not reflect the proportion either of registered or of found and recovered missing Serbs to missing non-Serbs (between 1:5 and 1:6). What it does reflect are the relative activity levels of the two commissions, which in turn reflect the financial resources allocated to the search and recovery process by the respective entity governments. ${ }^{105}$ Who is identified and repatriated depends above all on whose mortal remains are recovered. Rather than suspecting biases in the identification process, Serb families of missing persons could have addressed this issue and questioned the priorities of their own political authorities. Unfortunately, their justified frustrations and their fear of being under-prioritized in the MPI BiH as well have taken an increasingly ethnically discursive tone, including, among other things, unfortunate comparisons of their own victimization with the victimization of other family groups-accentuated by the lengthy and heavily politicized dispute over the socalled Sarajevo Commission, which has been ongoing since 2004 and has so far produced no results. ${ }^{106}$

\section{Clashes between Different Perceptions of Reality: The Search and Recovery Process}

Whereas the DNA identification process can be designed to be anonymous, the search and recovery process, by its very nature, cannot. To succeed in locating clandestine graves, one needs to known as precisely as possible for whom one is looking. Obviously, not all graves containing missing persons can be exhumed simultaneously. It has taken more than ten years to exhume about half the missing, and it may take another five to ten years to find and recover the rest. From a historical perspective, this will be a truly noteworthy achievement. However, life expectancy, not history, is the families' 
frame of reference: they fear they will not get an answer before they die. From this perspective, when one has already waited ten or fifteen years, waiting another ten years for an answer is very different from waiting another year. In total, the waiting may make up as much as one-third of a lifetime, and both the professionals and the families know very well that a number of missing persons will never be found or identified. Families cannot be certain that the outcome will be an answer, and, of course, no one will volunteer to wait in uncertainty. In addition, despite efforts to develop and start using scientific search methods, witness information is still the most important means of locating gravesites and determining what to expect when opening a grave. This adds another aspect to the time factor. Potential witnesses may be surviving victims, perpetrators, or bystanders; the incitement to conceal may be stronger than the incitement to reveal information that can lead to finding missing persons. Even if they want to give information, they may be threatened or intimidated into silence, with negative consequences for the search for missing persons. The passing of time may have both positive and negative consequences. On the one hand, witnesses may eventually be induced to come forward with the information they possess; on the other hand, important witnesses may die without having revealed their knowledge. This whole situation, in addition to the above-mentioned conflicts, illustrates how immensely important the criteria for deciding upon how to prioritize the order of search and recovery will become, as well as the huge conflicts the planning of exhumation seasons may create. This prioritization may be one of the biggest risk factors to be encountered by the new institute, and it may make or break the success of institutional and intergroup trust-building.

Criteria for prioritizing search and recovery must be perceived as fair and impartial by families of all ethnicities; this may be difficult to achieve, and to achieve it one may have to decide upon criteria that may very well not be the most efficient in terms of either time or costs. From my purely professional point of view as an archeologist, the most time- and cost-efficient course of action is to concentrate on and finish one complex of graves at a time. To see the graves in their context would make the work on each grave easier and allow the excavators to better reveal the pattern of events. In the case of complexes comprising both primary and secondary graves and containing dissociated and commingled human remains, such as those related to the Srebrenica genocide, it would also ease the work in subsequent phases of the process: the re-association of bones from the same individual found in several graves, as well as the identification process. It would furthermore lessen the emotional stress on families caused by having to bury partial bodies or reopen burials in order to add additional remains identified later. However, what professionals judge to be efficiency gains may appear different to families, given the ethnic discourse that still prevails. Whatever criteria are decided on in the end, it is essential that they be acceptable to the families and that Advisory Board members participate in the decision process. The paradox is that in order to avoid discrimination and create the perception among the families of missing persons of a process that is just to all, decision makers may have to take discriminating factors into account when planning search and recovery operations. One thing that it is not wise to do, however, is to exhume one grave in one locality one year, another grave in the same locality the next year, and perhaps a third grave the third year-even if this serves the purpose of keeping up awareness among local and international notabilities and potential donors. ${ }^{107}$ From a professional point of view, this is inefficient, and from a humanitarian point of view, it only prolongs the whole painful process, both for local communities and for the families whose missing relatives are buried in those graves. 


\section{Conclusions}

The establishment and implementation of the Law on Missing Persons and the MPI $\mathrm{BiH}$, based on principles of international humanitarian law and human rights, represent an increase of societal safety in $\mathrm{BiH}$. However, there is no guarantee that this issue will automatically be followed up by the MPI BiH in its operational phase unless specific attention is paid to it. It is a paradox that the Missing Persons Institute was created to be a trust-building institution, but cannot function without itself being trusted. This trust has been difficult to build. An instrumental rationality has been used to create the institutional and organizational frameworks and best practice operational standards that are needed to develop the qualities that promote institutional trust; a communicative rationality has been employed in an effort to ensure that the chosen solutions are commonly accepted by all actors involved. Far from being sequential and linear, however, as theoretically assumed, in reality the process has been spiraling forward, with many sidetracking and trust-destroying setbacks. The art has been to prevent the loops backward from becoming bigger than the loops forward. It is a paradox that consensus-seeking processes are necessary to build both institutional and intergroup trust but, when they draw out indefinitely, become trust destroying. This applies also in the present case. Consensus-seeking processes are difficult and time consuming-the more so the further apart the interested parties are and the less willing they are to compromise. The prevailing ethnic discourse, particularly in the political system, has made almost every decision along the way a truly cumbersome affair. The interested parties have been, and still are, quite far apart on a number of issues, and the noble art of compromise is not held in the greatest esteem. Because all board decisions within the MPI BiH are to be made by consensus, this dilemma will likely persist, clashing with the demand for efficiency and the goal of speeding up the resolution of the missing-persons issue.

The MPI BiH has the potential to mobilize the critical mass of people that is needed to create a positive reputational cascade effect, changing the public discourse from an ethnic discourse to a human-rights discourse. Within the MPI BiH, however, the human-rights discourse must compete with an ethnic discourse embedded in the very structure of the institute. This is partly unavoidable, since the institute's structure must comply with the consociational constitution of the BiH. Furthermore, the human-rights discourse must compete with the emotional rationality of the families of missing persons, which builds predominantly on the ethnic discourse. Despite sincere efforts to build bridging social capital among themselves, they are still prone to develop bonding social capital exploitable by divisive ethnic entrepreneurs. In addition, the directors of the MPI BiH have to some extend been stranded with the ethnically based practices of the former entity-level commissions. Since the directors are the institute's public face, in terms of trustworthiness, it is vitally important that they not bring these practices with them into the new institute but follow a common path and see to it that their staff do the same. They should settle their disputes among themselves, within the walls of the institute, rather than in public.

The families' emotional rationality feeds into a classical expert-versus-layperson dilemma. Solid facts that are perceived as self-explanatory by experts, such as the results of DNA analysis, are perceived differently by the families of the missing, who interpret the facts according to their own perception of reality. To put it simply, they have different frames of reference that create communication problems and lead to distrust. The professionals' historical time reference also clashes with the families' time reference (i.e., their own lifespan); what looks like a success from a historical 
perspective may seem a failure from a lifetime perspective. While professionals count bodies found and identified, families count their still-missing family members. In principle, professionals are not concerned about when particular missing individuals are recovered, as long as the recovery process is efficient and progresses steadily; to the families, when makes all the difference. Time- and cost-efficient recovery procedures may clash with families' perceptions of fairness and impartiality, making the criteria for deciding on the order of priority of exhumations/excavations a crucial trust-building factor.

In order to balance all these dilemmas, additional trust-building measures may be needed. Otherwise, contrary to intentions, the measures already employed may become trust destroying, the human-rights discourse the loser, and societal safety a fiction.

\section{Notes}

1. The official name of the state is Bosna i Hercegovina (Bosnia and Herzegovina). Throughout this article, I use the acronym BiH rather than the name "Bosnia," which has become widespread among contemporary writers but which, strictly speaking, refers to only one area of the country.

2. Law on Missing Persons, Official Gazette of Bosnia and Herzegovina No. 50/04 (9 November 2004). An unofficial translation into English is available on the Web site of the ICMP, http://www.ic-mp.org/wp-content/uploads/2007/11/lawmp_en.pdf (accessed 22 January 2009).

3. Law on Missing Persons, art. 7.

4. Agreement on Assuming the Role of Co-founders of the Missing Persons Institute of Bosnia and Herzegovina, Official Gazette of Bosnia and Herzegovina No. 13/05-International Agreements (29 December 2005) [MPI Agreement]. An unofficial translation into English is available on the Web site of the ICMP, http://www.ic-mp.org/wp-content/uploads/2007/ 11/agreement_en.pdf (accessed 22 January 2009).

5. Law on Missing Persons, arts. 21-23.

6. Ibid., art. 10.

7. Norwegian Centre for Human Rights, University of Oslo, "Description of the NORDEM Programme," http://www.humanrights.uio.no/programmes/nordem/about/ (accessed 29 June 2009).

8. I sincerely thank the persons who consented to participate in the interviews, which were both long and exhaustive, lasting between two and five hours, not including coffee breaks. I hope I have done them justice.

9. I want to express my sincere appreciation of the ICMP Press Office, and specifically press officer Jasmin Agović, who on a daily basis provides these press summaries and who always responds kindly to any request.

10. Norwegian Parliamentary White Paper No. 17 (2001-2002), "Societal Safety: The Road to a Less Vulnerable Society" (Oslo, 2002) [in Norwegian]. An English summary is available on the Web site of the Ministry of Justice and the Police, http://www.regjeringen.no/en/dep/jd/ Documents-and-publications/Reports/Reports/2002/Statement-on-Safety-and-Security-ofSoci.html?id=420173 (accessed 29 June 2009).

11. Odd Einar Olsen, Bjørn Ivar Kruke, and Jan Hovden, "Societal Safety: Concepts, Borders and Dilemmas," Journal of Contingencies and Crisis Management 15, 2 (2007): 69-79.

12. According to the World Values Survey, for several years Norway has had a generalized trust level of $65 \%$, lying in a cluster with the other Nordic countries, the Netherlands, Canada, and China.

13. UN Office for the Coordination of Humanitarian Affairs [UNOCHA], OCHA Orientation Handbook on Complex Emergencies (Geneva: UNOCHA, 1999), http://www.reliefweb.int/ library/documents/ocha_orientation_handbook_on_.htm (accessed 29 June 2009), 7. 
14. Uriel Rosenthal, Arjen Boin, and Louise K. Comfort, "The Changing World of Crisis and Crisis Management," in Managing Crisis: Threats, Dilemmas, Opportunities, ed. Uriel Rosenthal, Arjen Boin, and Louise K. Comfort, 5-27 (Springfield, IL: Charles C. Thomas, 2001); Celesta Kofman Bos, Susann Ullberg, and Paul't Hart, "The Long Shadow of Disaster: Memory and Politics in Holland and Sweden," International Journal of Mass Emergencies and Disasters 23, 1 (2005): 5-26.

15. Kirsten Juhl and Odd Einar Olsen, "Societal Safety, Archaeology and the Investigation of Contemporary Mass Graves," Journal of Genocide Research 8, 4 (2006): 411-35.

16. Judith E. Innes, Information in Communicative Planning (Working Paper 679, Institute of Urban and Regional Development, University of California at Berkeley, 1998), http://www.rmi.org/images/other/ER-InOpp-InfoCommPlng.pdf (accessed 22 January 2009).

17. Robert D. Putnam, Making Democracy Work: Civic Tradition in Modern Italy (Princeton, NJ: Princeton University Press, 1993)

18. Peter Håkansson and Fredrik Sjöholm, "Who do you trust? Ethnicity and Trust in Bosnia and Herzegovina" (EIJS Working Paper No. 216, European Institute of Japanese Studies, 2005), http://swopec.hhs.se/eijswp/papers/eijswp0216.pdf (accessed 2 July 2009), 3.

19. Bo Rothstein, Social Traps and the Problem of Trust (Cambridge: Cambridge University Press, 2005), 65-68.

20. Daniel Metlay,"Institutional Trust and Confidence: A Journey into a Conceptual Quagmire," in Social Trust and the Management of Risk, ed. George Cvetkovich and Ragnar E. Löfstedt, 100-116 (London: Earthscan Publications, 1999), 101.

21. Ibid.

22. Rothstein, Social Traps, i.

23. John Platt, "Social Traps," American Psychologist 28, 8 (1973): 641-51.

24. Rothstein, Social Traps, 12.

25. Ibid., 12-26.

26. Joel Brockner and Jeffrey Z. Rubin, Entrapment in Escalating Conflicts (New York: Springer, 1985), 5.

27. Russell Hardin, "Conceptions and Explanations of Trust," in Trust in Society, ed. Karen S. Cook, 3-39 (New York: Russell Sage Foundation, 2001); Russell Hardin, Trust and Trustworthiness (New York: Russell Sage Foundation, 2002); Russell Hardin, Trust (Cambridge: Polity Press, 2006).

28. Bo Rothstein, "Social Capital, Economic Growth and Quality of Government: The Causal Mechanism," New Political Economy 8, 1 (2003): 49-47; Rothstein, Social Traps, 59-68.

29. Rothstein, Social Traps, 106-17.

30. Ibid., 122. See also Joel Brockner and Phyllis Siegel, "Understanding the Interaction between Procedural and Distributive Justice: The Role of Trust," in Trust in Organizations: Frontiers of Theories and Research, ed. Roderick Moreland Kramer and Tom R. Tyler, 390-413 (Thousand Oaks, CA: Sage 1996).

31. Paul Slovic, "Perceived Risk, Trust, and Democracy," in Social Trust and the Management of Risk, ed. George Cvetkovich and Ragnar E. Löfstedt, 42-52 (London: Earthscan Publications, 1999).

32. Toshio Yamagishi, "Trust as a Form of Social Intelligence," in Trust in Society, ed. Karen S. Cook, 121-47 (New York: Russell Sage Foundation, 2001).

33. Murat Somer, "Insincere Public Discourse, Inter-Group Trust, and Implications for Democratic Transition: The Yugoslav Meltdown Revisited," Journal for Institutional Innovation, Development and Transition 6 (2002): 92-112.

34. Robert D. Putnam, Bowling Alone: The Collapse and Revival of American Community (New York: Simon \& Schuster, 2000), 134-47.

35. Rothstein, "Social Capital," 50; Rothstein, Social Traps, 55-56.

36. Mark Baskin and Paula M. Pickering, "Former Yugoslavia and Its Successors," in Central and East European Politics: From Communism to Democracy, ed. Sharon L. Wolchik and Jane L. Curry, 281-316 (Lanham, MD: Rowman \& Littlefield, 2007), 301. 
37. Paula M. Pickering, "Generating Social Capital for Bridging Ethnic Division in the Balkans: Case Studies of Two Bosniak Cities," Ethnic and Racial Studies 29, 1 (2006): 79-103.

38. Slovic, "Perceived Risk."

39. James G. March and Johan P. Olsen, "The Uncertainty of the Past: Organizational Learning under Ambiguity," European Journal of Political Research 3 (1975): 149-71.

40. T.K. Das and Bing-Sheng Teng, "Trust, Control, and Risk in Strategic Alliances: An Integrated Framework," Organization Studies 22, 2 (2001): 252-83.

41. Katinka Bijisma-Frankema and Ana Cristina Costa, "Understanding the Trust-Control Nexus," International Sociology 20 (2005): 259-82, 259.

42. Putnam, Making Democracy Work, 180; Slovic, "Perceived Risk."

43. Peter Håkansson and Sarah Hargreaves, Trust in Transition-Generalised Trust in Bosnia and Herzegovina (Sarajevo: Balkans Analysis Group, 2004), http://www.balkansanalysis.org/reports/trust-in-transition.pdf (accessed 30 June 2009); see also Håkansson and Sjöholm, "Who do you trust?."

44. All EWS reports since 2002 are available at http://www.undp.ba/index.aspx?PID=14 (accessed 2 July 2009).

45. Justice and Truth in BiH: Public Perceptions (Sarajevo: UNDP BiH, 2005), http:// www.undp.ba/index.aspx?PID=14 (accessed 2 July 2009).

46. Both surveys defined generalized trust as "trust that extends beyond the boundaries of face-to-face interaction and incorporates people not personally known" and measured it by the question "Generally speaking, would you say that most people can be trusted or that you can't be too careful in dealing with people?"

47. Håkansson and Hargreaves, Trust in Transition, fig. 3.1.

48. Ibid., fig. 4.1.

49. The equivalent question in the EWS surveys until 2002 addressed "confidence in the work of"; from 2003 on, the question used the phrase "approval of the work of" a number of governance structures and executive bodies, except the army.

50. The OHR was established as part of the Dayton Peace Agreement as an ad hoc institution to oversee the implementation of civilian aspects of the agreement on behalf of the international community through the Peace Implementation Council (fifty-five countries and agencies). See http://www.ohr.int/(accessed 22 January 2009). See General Framework Agreement for Peace in Bosnia and Herzegovina (14 December 1995), annex 10,

"Agreement on Civilian Implementation," http://www.ohr.int/dpa/ default.asp?content_id=366 (accessed 3 July 2009).

51. Status of Activities pertaining to the Implementation of the Missing Persons Institute in BiH (ICMP.GR.23.2.doc, 7 February 2007), ch. II.1 [MPI Status Report].

52. See note 2 .

53. Predominantly Additional Protocol I, art. 32. For a useful short overview of the various articles in international humanitarian law pertaining to families' right to know the fate of relatives see ICRC, Support to Families of People Unaccounted For (Geneva: ICRC, 2002) s. 2.1.2, http://www.icrc.org/Web/eng/siteeng0.nsf/htmlall/5CBDZG/\$File/ ICRC_TheMissing_082002_EN_4.pdf (accessed 3 July 2009).

54. Promotion and Protection of Human Rights: Study on the Right to the Truth (Report of the OHCHR), UN Doc. E/CN.4/2006/91 (8 February 2006), http://daccessdds.un.org/doc/ UNDOC/GEN/G06/106/56/PDF/G0610656.pdf?OpenElement (accessed 3 July 2009).

55. Law on Missing Persons, arts. 3, 8.

56. Ibid., arts. 11-17, 18, 9 .

57. In line with the definitions put forth by George Cvetkovich and Timothy C. Early, "The Construction of Justice: A Case Study of Public Participation in Land Management," Journal of Social Issues 50 (1994): 161-78, 163, public participation is here understood as the direct involvement of individual citizens and citizen groups in information-seeking, decision-making, and public planning processes. As stated by Cvetkovich and Early, public participation may be enacted through a variety of forms, from participating in public 
surveys, hearings, and citizen advisory boards to exercising actual decision-making powers. The degree of involvement may likewise vary from one-time involvement, through short-term involvement in parts of a process, to sustained, long-term involvement with direct power over outcomes. The concept does not include voting in general elections or on referendums or the lay participation in political or legal institutions (e.g., serving on a jury).

58. Law on Missing Persons, arts. 4-6.

59. Large parts of the $\mathrm{BiH}$ Law on Missing Persons are echoed, or reproduced verbatim, in Guiding Principles / Model Law on the Missing: Principles for Legislating the Situation of Persons Missing as a Result of Armed Conflict or Internal Violence: Measures to Prevent Persons from Going Missing and to Protect the Rights and Interests of the Missing and Their Families (ICRC Advisory Service on International Humanitarian Law, September 2007), http://www.icrc.org/Web/eng/siteeng0.nsf/htmlall/missing-model-law-010907/\$File/ Model\%20law.missing-0907_eng\%20.pdf (accessed 3 July 2009). See also Missing Persons and Their Families: Recommendations for Drafting National Legislation (ICRC Advisory Service on International Humanitarian Law, October 2003), http://www.icrc.org/Web/Eng/ siteeng0.nsf/htmlall/5T6E5T/\$File/Missing_and_Recommendations_Missing.pdf (accessed 3 July 2009).

60. Jens Rasmussen, "Risk Management in a Dynamic Society: A Modelling Problem," Safety Science 27, 2/3 (1997): 183-213.

61. This document was issued in Bosnian, Croatian, Serbian, and English. For English version see Application of the Law on Missing Persons of Bosnia and Herzegovina: Guide for Families of Missing Persons (Sarajevo: Ministry for Human Rights and Refugees, 2006), http://www.ic-mp.org/wp-content/uploads/2007/11/vodic_web_en.pdf (accessed 3 July 2009).

62. International Commission on Missing Persons [ICMP], "Bosnia and Herzegovina" (2008), http://www.ic-mp.org/icmp-worldwide/southeast-europe/bosnia-and-herzegovina/ (accessed 3 July 2009); OHR Human Rights/Rule of Law Department, "Domestic War Crime Trials and Exhumations" (Office of the High Representative and EU Special Representative, September 2001), http://www.ohr.int/ohr-dept/hr-rol/thedept/war-crime-tr/ default.asp?content_id=5231 (accessed 3 July 2009).

63. MPI Status Report, ch. II.2.

64. ICMP, "Missing Persons Institute Launched on International Day of the Disappeared" (Press release, 30 August 2005), http://www.ic-mp.org/press-releases/missing-personsinstitute-launched-on-international-day-of-the-disappeared/\#more-441 (accessed 3 July 2009).

65. MPI Agreement (see note 4).

66. Ibid., art. 13.

67. Ibid., art. 14.

68. "Kathryne Bomberger, ICMP Chief of Staff, Search for the missing will not be over when ICMP leaves," Dneuni avaz (6 November 2005), 5. Unless otherwise noted, all such citations are to English-language press summaries provided by Jasmin Agović of the ICMP; author names and page numbers are provided when this information was included in the ICMP summary.

69. Decision on appointing the acting members of the Board of Directors in the Missing Persons Institute (Council of Ministers of Bosnia and Herzegovina, 107th session, 9 February 2006), signed by the co-founders on 28 February 2006.

70. Decision on Cessation of the Decision on Establishment of the State Commission on Tracing the Missing Persons, Official Gazette of Bosnia and Herzegovina No. 22/06 (28 March 2006); Decision on Transfer of Jurisdiction from the Office for Tracing Detained and Missing Persons of Republika Srpska to MPI, Official Gazette of Republika Srpska No. 65/06 (29 June 2006); Decision on Cessation of the Decision on Establishment of the Federation Commission on Missing Persons, Official Gazette of Federation of BiH No. 55/06 (20 September 2006). The Republika Srpska decision had to be supplemented on 5 October to make its entry into force pending the establishment of the MPI. 
71. MPI Status Report, ch. II.7; ICMP, "First Meeting of MPI Governance Structures" (Press release, 27 June 2007), http://www.ic-mp.org/press-releases/first-meeting-of-mpigovernance-structures/\#more-516 (accessed 3 July 2009).

72. ICMP, "ICMP Welcomes BiH CoM's Decision" (Press release, 30 November 2007), http:// www.ic-mp.org/press-releases/icmp-welcomes-bih-coms-decision/\#more-600 (accessed 3 July 2009).

73. MPI Agreement, art. 15. See, e.g., Nataša Krsman, "Disagreements about Setting up the State Institute on Missing Persons," Glas Srpske (28 January 2005); "The Work of the Missing Persons Institute Depends on appointment of future directors," Nezavisne novine (10 April 2005).

74. Law on Missing Persons, art. 5.

75. UNDP Bosnia and Herzegovina, Citizens' Guide to the Government Institutions of the Federation of Bosnia and Herzegovina, 2nd ed. (November 2003), http://www.undp.ba/ index.aspx?PID=36\&RID=20 (accessed 3 July 2009).

76. E.g., "Bukejlović no Manners," DANI (6 May 2005), 10; "RS Families of Missing Request Exclusion of Mašović from Collegium," Bosnia Daily (10 March 2006); "Union of Associations of the Families of the Missing wrote to the BiH Electoral Commission: Laws violated," Nezavisne novine (12 March 2006); “Justified Fear," Glas Srpske (14 March 2006).

77. E.g., "Mašović Is Salt on Our Wounds," Glas Srpske (18 July 2007), 2.

78. "Jasminka Džumhur, Chair of the BiH Missing Persons Institute Steering Board: The Mandate Has Not Expired," Glas Srpske (9 October 2007); SRNA, "Brano Dursun: Mašović Has Nothing to Do in the Institute," Nezavisne novine (12 October 2007), 3.

79. F. Vele, "Why Exhumed Victims Were Not Identified: The RS Team Failed to Do Their Job Right," Dnevni avaz (3 November 2007), 11; E.B., "Milan Bogdanić Responds to Mašović: RS Team Is Not Responsible for Anybody's Incompetence," Dnevni avaz (4 November 2007), 4.

80. MPI Status Report, chs. II.3-II.5, II.8.

81. The General Framework Agreement for Peace in Bosnia and Herzegovina, Annex 4: Constitution of Bosnia and Herzegovina" (14 December 1995), http://www.ohr.int/dpa/ default.asp?content_id=372 (accessed 3 July 2009).

82. Sumantra Bose, Bosnia after Dayton: Nationalist Partition and International Intervention (London: Hurst \& Co., 2002), 216-17, 246-52.

83. ICMP, "Family Associations of Missing Demand Functioning of MPI Before End of Year" (Press release, 8 December 2006), http://www.ic-mp.org/press-releases/family-associationsof-missing-demand-functioning-of-mpi-before-end-of-year/\#more-497 (accessed 3 July 2009).

84. ICMP, "MPI Steering Board Members Nominated by Council of Ministers" (Press release, 29 December 2006), http://www.ic-mp.org/press-releases/mpi-steering-board-membersnominated-by-council-of-ministers/\#more-499 (accessed 3 July 2009).

85. Sanita Rožajac, "Forming of the BiH Missing Persons Institute: Only Milijana Bojić Is Disputed," Oslobođenje (10 January 2007), 7; "Srebrenica Women Protest against New MPI Head," Bosnia Daily (13 January 2007), 4; G. Klepić, "Milijana Bojić on Accusations from F BiH: Attacks with No Evidence," Glas Srpske (20 January 2007), 2; "Resistance to Appointing Milijana Bojić to Steering Board: Srebrenica Associations Threaten with Boycott of the Missing Persons Institute," Dnevni avaz (6 February 2007), 12; "Srebrenica Women Protest over MPI Board Candidate," Bosnia Daily (6 February 2007), 5.

86. T. Lazović, "BiH Council of Ministers Session: Halilović: "Someone Would Like for the Institute not to Function," Dneuni avaz (25 May 2007), 5.

87. Law on Missing Persons, art. 2, para. 1.

88. As of 25 January 2005. ICMP, personal communication with author, 2005.

89. As of 1 November 2007, the number of missing persons registered with ICRC was 22,373, of whom 9,386 had been identified: "Search for 12,987 Missing Persons," Nezavisne novine (23 November 2007), 2. As of 23 November 2007, blood samples provided to the ICMP 
represented 22,934 missing persons, of whom 10,781 individuals had been identified: ICMP, Tracking Chart by Conflict and Area of Disappearance (23 November 2007).

90. ICMP, Tracking Chart by Conflict and Area of Disappearance (28 March 2008).

91. This number represents cases closed by the court-appointed local pathologist in charge, who makes the official identification only after having compared all existing evidence on the identity of the person in question and having informed and obtained the approval of the person's family. DNA matching reports are just one type of evidence, albeit one with at least a $99.95 \%$ statistical probability of being correct.

92. Readers should keep in mind that all of these figures change on a daily basis.

93. Law on Missing Persons, art. 2, para. 2.

94. Where no other source is specified, the discussion that follows is based on information provided by family-association representatives or by the ICMP Department of Civil Society Initiatives (CSI), including the latter's Directory of Associations of Families of Missing Persons (November 2007 version).

95. One such incident occurred at the Ninth Regional Networking Conference, held in Brčko in November 2006, where the representatives of Serb family associations from across the former Yugoslavia refused as a group to visit a nearby mass gravesite under exhumation by the Federal Commission and gave reasons that were not acceptable to representatives of other family associations.

96. Vedran Persic, "MPI Is Way Forward in Search for Missing," Bosnia Daily (20 July 2007), 3.

97. ICMP, "Families Are Driving Force for Institute" (Press release, 26 August 2005), http://www.ic-mp.org/press-releases/families-are-driving-force-for-institute/\#more-438 (accessed 3 July 2009).

98. “Milijana Bojić: No more humiliation!" Glas Srpske (10 September 2005), 3.

99. In Brčko, for example, there is a family association for each of the three constituent peoples; in Biljeljina, there are two Bosniak and two Serb associations; in Mostar, two Croat and one Bosniak association; in Prijedor, two Bosniak and one Serb association; and eight associations are based in Tuzla: six Bosniak, one Croat, and the Roma association.

100. Elissa Helms, "Women as Agents of Ethnic Reconciliation? Women's NGOs and International Intervention in Postwar Bosnia-Herzegovina," Women's Studies

International Forum 26, 1 (2003): 1-23, calls this an "affirmative gender essentialism." Helms shows how powerful a strategy this may be in interactions both with foreign donors and with the formal, male-dominated domestic political sphere. But she also shows how, in the end, it may become counterproductive by excluding women's associations from this very sphere.

101. The term missing person thus defines a much broader category of people than is included under the term disappeared person, as used in the UN Declaration on the Protection of All Persons from Enforced Disappearances; see Report on the Enjoyment of the Rights of Families of Missing Persons in Bosnia and Herzegovina (Office of the United Nations High Commissioner for Human Rights, Field Office in Bosnia and Herzegovina, May 2005), an unpublished report widely disseminated among local and international actors in the country.

102. "Šejkovača Identification Center: 251 Bodies Unidentified," Nezavisne novine (3 April 2007), 9; N. Ćano, "Dozens of Roma Await Identification," Oslobođenje (10 April 2007), 6.

103. "Identifications in Republika Srpska: Body of Mile Simanić [Lay] in Lukavica for Almost 9 Years," Dnevni avaz (6 April 2007), 12; "Why Silence for Eight Years?" Oslobođenje (8 April 2007), 4; G. Klepić, "Families of the Missing Request Meeting with Prime Minister Dodik: Starting Over with the Institute," Glas Srpske (11 April 2007), 4; B. Bugarin, Glas Srpske (23 April 2007), 2.

104. G. Klepić, "International Commission on Missing Persons on Nedeljko Mitrović's Statements: No Room for Doubts," Glas Srpske (13 April 2007), 4.

105. In recent years, the Federation of Bosnia and Herzegovina has allocated ten times as much money to the Federal Commission $(\mathrm{KM} 3,000,000)$ as the Republika Srpska has allocated to 
RS Office (KM300,000). “Ashdown's Last Strike Against the Dead!” Oslobođjenje (27 May 2005), cover, 4-5.

106. For an overview see Mirna Buljugic, "No Progress for Sarajevo Truth Commission," Birn Justice Report (23 February 2007), http://www.birn.eu.com/en/71/10/2344/(accessed 6 July 2009); Nidzara Ahmetasevic, "Between Truth and Politics," BIRN Justice Report (2008), http://www.bim.ba/en/18/10/928/?tpl=58 (accessed 6 July 2009).

107. One example are the Budak graves, which are so conveniently close to the Potočari Memorial Center that they have been reserved as showcases. Since 2005, one grave has been exhumed every year in connection with the anniversary of the fall of Srebrenica. One of these exhumations was also visited by participants in the International Association of Genocide Scholars' Seventh Biennial Meeting in Sarajevo in 2007; see the conference program at http://genocidescholars.org/images/brosura_IAGS_0207.pdf (accessed 6 July 2009). 